\title{
Economic Efficiency of Sorghum and Millet Production for Small Scale Farmers in Traditional Rainfed, North Kordofan State, Sudan
}

\author{
Ibrahim Elnour Ibrahim*
}

University of Kordofan, Faculty of Natural Resources and Environmental Studies, Department of Agricultural Economics and Agribusiness Elobeid-Sudan. PO Box 160

\begin{tabular}{l}
\hline A R T I C L E I N F O \\
Research Article \\
Received 29 August 2017 \\
Accepted 09 October 2017 \\
\hline
\end{tabular}

Keywords:

Farm efficiency

Stochastic frontier approach

Cost function

Field crops

Africa

\begin{abstract}
A B S T R A C T
The purpose of this study was to measure and analyse the economic efficiency, and to identify the main factor behind economic efficiency of sorghum and millet for small scale farmers in traditional rainfed sector in North Kordofan State. Primary data is collected using structured questionnaire for a sample of 205 farmers from four localities namely (Sheikan, Umrwaba, Elnuhoud, and Elkhowi). Stochastic frontier approach (cost function) was used to analyse economic efficiency and descriptive statistics were used to analyse socio-economic characteristics of farmers. The results of stochastic frontier cost function revealed that the estimated economic efficiency of the sorghum and millet farmers obtained was found the mean economic efficiency to be $39 \%$ and $15 \%$, respectively. The economic efficiency is very weak, because most parameters and inefficiency effect factor found to be not significant, these determinants may give a clear picture of farmers that could be targeted in order to increase efficiency
\end{abstract}

\footnotetext{
*Corresponding Author:

E-mail: ibrahim_elnour@yahoo.com

DOI: https://doi.org/10.24925/turjaf.v6i2.150-155.1490
}

\section{Introduction}

Agriculture has played a key role in the development of human civilization. Until the industrial revolution, the vast majority of the human population labored in agriculture. Development of agricultural techniques has steadily increased agricultural productivity, and the widespread diffusion of these techniques during a time period is often called an agricultural revolution. A remarkable shift in agricultural practices has occurred over the past century in response to new technologies (Anonymous, 2017a).

Rain-fed agriculture is the source of subsistence and work for about $70 \%$ of Sudan's population and accounts for $90 \%$ of its farmland. The most vital food and cash crops are produced in this sector. Some $78 \%$ of sorghum grain, $99 \%$ of pearl millet, $100 \%$ of sesame and $71 \%$ of groundnuts' production is rain-fed and almost all crop production of the South. Promising crops like maize, sunflower, guar, rice and grain legumes are expected to be fully or predominantly rain-fed. As Sudan exhausts its share of the Nile waters, rain-fed production will attain a still greater role. Traditional farming has been the base of the country's agriculture since times immortal. It depends on family labor using simple hand tools, and confined to lands where permanent sources of water supplies were assured (Mohamed and Mahmoud, 2009).
Cereals are the major crops produced in Sudan, are fast growing (Hashemi et al., 2013; Sadeghpour et al., 2013a), drought tolerant (Jahanzad et al., 2013; Zandvakili et al., 2013) and high yielding crops (Esmaeili et al., 2011; Sadeghpour et al., 2013b) which often require limited resources to produce acceptable yield in arid and semi-arid conditions (Zandvakili et al, 2012; Sadeghpour and Jahanzad, 2012; Sadeghpour et al., 2014). During the period 2006-2009, the average cereal area annually harvested was about 8.2 million hectares, of which nearly 726,000 hectares or $8.8 \%$ was Irrigated, 3.4 million hectares or $41.4 \%$ was under mechanized rain-fed, and 4.1 million hectares or $49.7 \%$ was under traditional rainfed farming system. The average cereal production obtained during the same period was about 4.9 million metric tons, consisting of 3.7 million metric tons of sorghum or $75.6 \%$ of total cereal production, 622,000 metric tons of millet (12.6\%), and 578,000 metric tons of wheat or $11.7 \%$ of total cereal production. Whereas the traditional rain-fed farming system accounts for $49.7 \%$ of total cereal area harvested, but contributes $36.5 \%$ to total cereal output (FAO, 2010).

More than $75 \%$ of the population in North Kordofan state, in western Sudan, depends on agriculture as their main source of food and income. 
Agriculture in North Kordofan State is integral part of traditional farming, before three decades' productivity was high and household used to cover all grain or cereal needs from farm production i.e. through direct access. Over the years crop production has fluctuated due to many factors such as low/erratic rainfall, pest infestation and low soil fertility. The area has experienced high environmental degradations; resulted in declined productivity and depletion of large livestock herds along with plant species which makes most of the rural people living in highly vulnerable conditions. Accordingly, the area continuously experienced food gaps or food insecurity and getting food aids (Sayed et al, 2014).

\section{Materials and Methods}

\section{Study Area}

The study was carried out in North Kordofan lies in the dry zone in central Sudan between latitudes 15-11 and 45-16 north and Lengths 5 - 27.15-32 east. Bordered by six states northern state from the north, Khartoum State and White Nile from the east, South Kordofan in the south, South Darfur from the south-west and North Darfur in the west. North Kordofan state covers an area of 244,700 square $\mathrm{km}$ meters, equivalent to 139 square miles and 58.8 million acres of land.

\section{Data Collecting}

Primary and secondary data are used to fulfill the objectives of the study. Primary data was collected by distributing structural questionnaire following stratified random sampling techniques due to socio-economic characteristic and homogeneity of North Kordofan population, select 205 respondents. The primary data include basic information about the socio-economic characteristics, crops production cost and prices of inputs and output.

\section{The Stochastic Frontier Cost Functions}

Coelli (1996) cited that if we wish to specify a stochastic frontier cost function, we simply alter the error term specification from: $(\mathrm{Vi}-\mathrm{Ui})$ to $(\mathrm{Vi}+\mathrm{Ui})$. For example, this substitution would transform the production function defined by (1) into the cost function:

$$
Y_{i}=x_{i} \beta+\left(V_{i}+U_{i}\right)
$$

\section{Where}

$Y_{i}$ is the (logarithm of the) cost of production of the $i-$ th firm; $x_{i}$ is a $k \times 1$ vector of (transformations of the) input prices and output of the i-th firm; $\beta$ is an vector of unknown parameters; the $\mathrm{V}_{\mathrm{i}}$ are random variables which are assumed to be iid $\mathrm{N}\left(0, \sigma \mathrm{V}^{2}\right)$, and independent of the $\mathrm{U}_{\mathrm{i}}$ which are non-negative random variables which are assumed to account for the cost of inefficiency in production, which are often assumed to be iid $\left|\mathrm{N}\left(0, \sigma_{\mathrm{U}}{ }^{2}\right)\right|$.

In this cost function the $U_{i}$ now defines how far the firm operates above the cost frontier. If allocative efficiency is assumed, the $\mathrm{U}_{\mathrm{i}}$ is closely related to the cost of technical inefficiency. If this assumption is not made, the interpretation of the $U_{i}$ in a cost function is less clear, with both technical and allocative inefficiencies possibly involved. The exact interpretation of these cost efficiencies will depend upon the particular application.

\section{Stochastic Frontier Model Building}

The stochastic frontier cost function model for estimating farm level overall economic efficiency is specified as:

$$
\left[\operatorname{Ln} y_{i}=\beta_{0}+\beta_{1} x_{1}+\cdots+\beta_{9} x_{9}+\left(v_{i}+u_{i}\right)\right]
$$

Where:

$\ln =$ the natural logarithm; $\mathrm{Y}_{\mathrm{i}}=$ the total output; $\mathrm{X}_{1}=$ the area in feddan cost; $X_{2}=$ the cleaning processing cost; $\mathrm{X}_{3}=$ the ploughing cost; $\mathrm{X}_{4}=$ sowing cost, $\mathrm{X}_{5}=$ weeding cost, $X_{6}=$ seeds cost $; X_{7}=$ fertilizer cost $; X_{8}=$ pesticides cost, and $\mathrm{X}_{9}=$ harvesting cost $\beta_{0}$ and $\beta_{1}$ are unknown parameters to be estimated for variables, respectively. $v_{i}$ represents the statistical error and the other factors which are beyond the farmers control such as weather, topography and others factor which are not included and may be positive, negative or zero. $\mathrm{u}_{\mathrm{i}}$ is a non-negative random variables which are assumed to account for the cost of inefficiency in production, which are often assumed to be iid $\mid \mathrm{N}\left(0, \delta \mathrm{u}^{2} \mid\right.$.

The level of inefficiency of the farmers which specified as:

$$
\mu \mathrm{i}=\delta \mathrm{o}+\sum_{\mathrm{s}=1}^{8} \delta \mathrm{s} \mathrm{Zsi}
$$

Where:

$\mathrm{Z}_{1 \mathrm{i}}=$ age of farmers; $\mathrm{Z}_{2 \mathrm{i}}=$ farming experience (years of active farming); $Z_{3 i}=\operatorname{sex}$ (dummy) $1=$ male, $0=$ female; $Z_{4 i}=$ educational level of farmers (years spend in school); $Z_{5 \mathrm{i}}=$ marital status of farmers; $Z_{6 \mathrm{i}}=$ household size (number); $Z_{7_{\mathrm{i}}}=$ credit access (dummy) $1=$ access, $0=$ no access; $Z_{8 \mathrm{i}}=$ extension services contact (dummy) $1=$ contact, $0=$ non-contact; $\delta_{\mathrm{o}}$ and $\delta_{\mathrm{s}}$ coefficient are unknown parameters to be estimated, together with the variance parameters which area expressed in terms of $\sigma^{2}$ $=\sigma^{2} u+\sigma^{2} v$ and $\gamma=\sigma^{2} u / \sigma^{2}$. Where the $\gamma$-parameters has value between zero and one. If $\gamma$ has a value of one this will indicate that differences in farmers output due to technical inefficiency. A value of zero for, $\gamma$, indicates that the differences mainly due to statistical errors (Mohamed et al, 2009).

\section{Results and Discussion}

Descriptive Statistics Analysis of Farm Household's Socio-Economic Characteristics

As shown in the Table 1: The analysis of socioeconomic characteristics of the respondents revealed that majority of household heads $(76 \%)$ were males of total respondent's distribution in North Kordofan State.

The age of the farmers ranged between 23 and 80 years. Majority of the respondents $(46.3 \%)$ were between the age of 31 and 40 years. The mean age was 44 years. This implies that majority of the farmers were youth; an 
economic active age that can make positive contribution to agricultural production. Age structure is one of the factors that are used to distinguish the farming systems, Siddig (1999) reported that a farmer's age is one of his demographic characteristic which influences the quality of his decision and his attitude toward accepting new ideas.

Younger farmers tend to have better education and are often expected to be more willing to innovate (Ranaivoarision, 2004).

The survey showed that most of the farmers $(63.4 \%)$ have attained some sort of education. In the study area, $31.7 \%$ of respondents had secondary education, this level of education indicators that the farmers level of awareness and their abilities of take decisions on how and what to produce, and adopting new agricultural technologies, and manage inputs, which means that the technical inefficiency effect increase with increase with education of farmers. Education in general can be defined as accumulation of knowledge and experience to prepare an individual for life (Ahmed, 1996 and Siddig, 1999). Education stimulates people to realize their needs to under-stand the problems of their immediate environments and their rights and duties as citizens (Malik, 1984).

The farming experience was ranged between 2 and 30 years of experience with mean of 12.7 years. The $48.8 \%$ of the respondents ranged between 11 and 20 years of farming experience, and this shows that the managerial ability of the farmers can be inferred to be reasonably good.

The household size farmers ranged between 2 and 10 members with mean 5.4 members. Most respondents $(51.2 \%)$ household size ranged between 6 and 10 members.

Land tenure is the name given, particularly in common law systems, to the legal regime in which land is owned by an individual, who is said to "hold" the land. The sovereign monarch, known as held land in its own right all private owners are either its tenants or subtenants. The term "tenure" is used to signify the relationship between tenant and lord, not the relationship between tenant and land (Anonymous, 2017b).

As depicted in Table 1, agriculture is the main occupation of the respondents in study area, which were mostly $(92.7 \%)$ of sample respondents are farmers. The study revealed that most of farmers $(53.7 \%)$ land tenure acquired through owned. Otherwise, (65.4\%) of respondents not access to credit to finance their agriculture, and (80\%) of respondents non-contact with extension service, and $(80.5 \%)$ of farmers not membership of cooperative society.

\section{Estimated Cost Function}

The parameters of the cost frontier can be estimated using standard econometrics methods since the output and price of inputs are assumed to be exogenously determined. Schmidt and Lovell (1977) showed that the stochastic cost frontier can be estimated in a similar manner to the stochastic production frontier ML estimators. The estimates of the parameters of stochastic frontier cost function for sorghum and millet were presented in Table 2.

As shown in Table 2, the economic efficiency analysis of sorghum and millet of farmers revealed that there were presences of costs inefficiency effects in production as confirmed by the significant gammas values of 0.99 for sorghum and millet. This implies that about $99 \%$ variation in the total production cost for sorghum, and millet are due to differences in their costs efficiencies. According to the frontier results, and as shown in Table 3, the frequency distribution of economic efficiency, the economic efficiency of sorghum was ranged between 0.13 and 0.93 with mean of 0.39 , which means that if the average farmer were to reach the economic efficiency level of its most efficient counterpart, then he could experience a cost saving of 59\% (i.e. 1-(39/93)). In other words, in principle, that the sample farms could potentially reduce their overall cost of sorghum production by approximately $59 \%$ and still attain the current output level.

The average economic efficiency score of millet was $15 \%$. This means that the millet farms use the combination of inputs at a cost inefficiencies level, they could potentially reduce their overall cost by $85 \%$ and still attain the current output level.

The estimated coefficient of the parameters of stochastic frontier cost function of sorghum and millet were presented in Table 2. The estimated coefficient of the variables (cost of farm area, cost of land preparation, tillage cost, sowing cost, weeding cost, seeds cost, fertilizers cost, pesticides cost and cost of harvesting) used in regression analysis some of this variable was found to be positive and significant, and other negatively significant. The positive and significant variables imply that the cost of variable used have direct relationship with total cost of production used as output. In other words, cost of variables increase by the value of each coefficient as the quantity of each variable is increased by one. The negatively significant variables imply that the cost of variable used have indirect relationship with total cost of production used as output.

\section{Economic inefficiency model}

The economic inefficiency parameters are specified as those relating to farmers' specific socioeconomic characteristics. We may know that the inefficiency effect, $\mathrm{U}$, is added in the cost frontier, instead of being subtracted, as in the case of the production frontier. This is because the cost function represents minimum cost, whereas the production function represents maximum outputs.

These include the age, sex, educational levels, years of experiences, marital status, family size, access to credit and extension services contact. As shown in Table 2. The coefficient of age variable is estimated to be negative and statistically significant at 0.01 levels for sorghum and millet. The negative significant age of farmers indicates that farmers who are older are relatively more efficient in crop production. 
Table 1 Descriptive statistics result of household characteristics

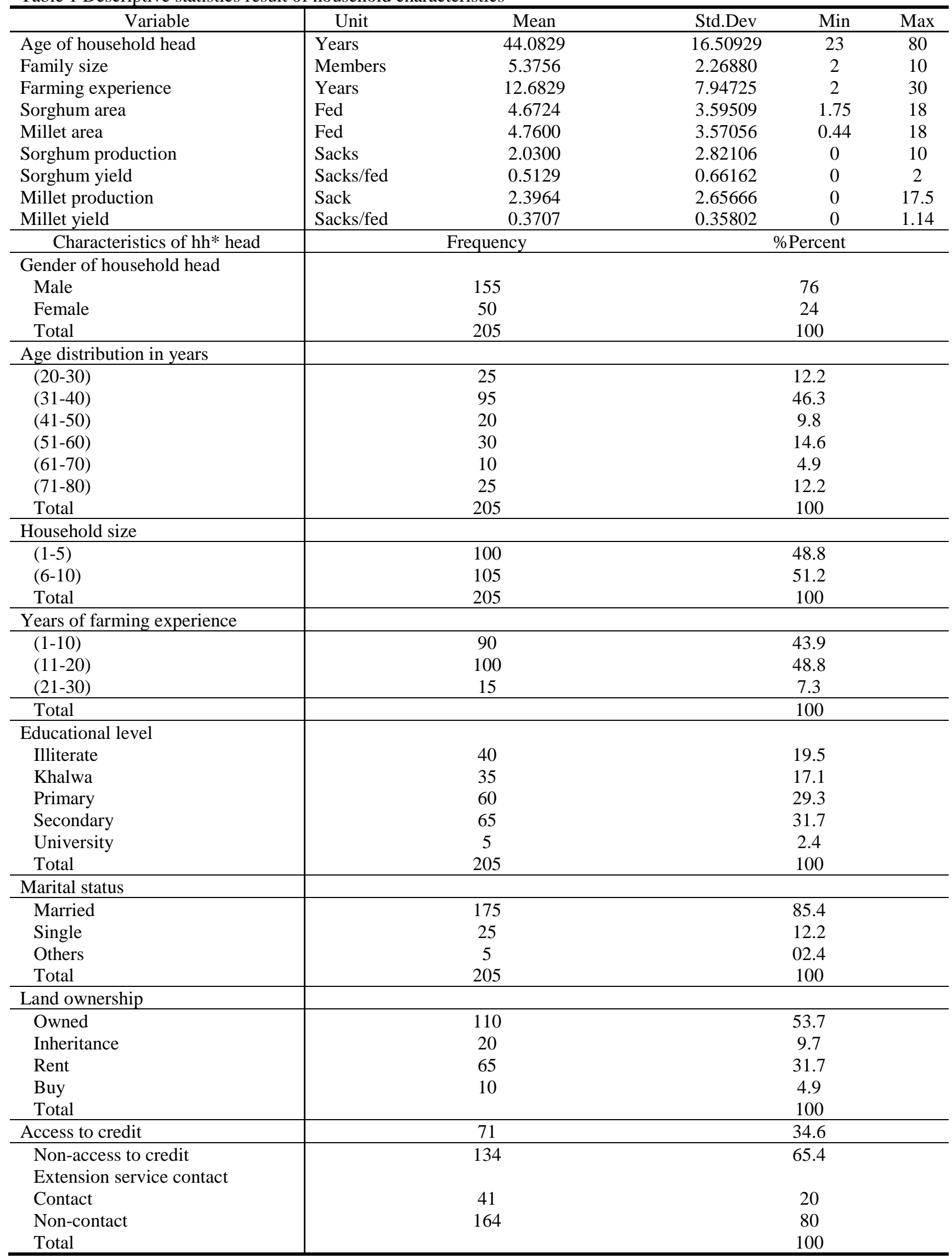


Table 2 Maximum-likelihood estimate for the parameters of the stochastic frontier cost function and cost inefficiency effect model for sorghum and millet

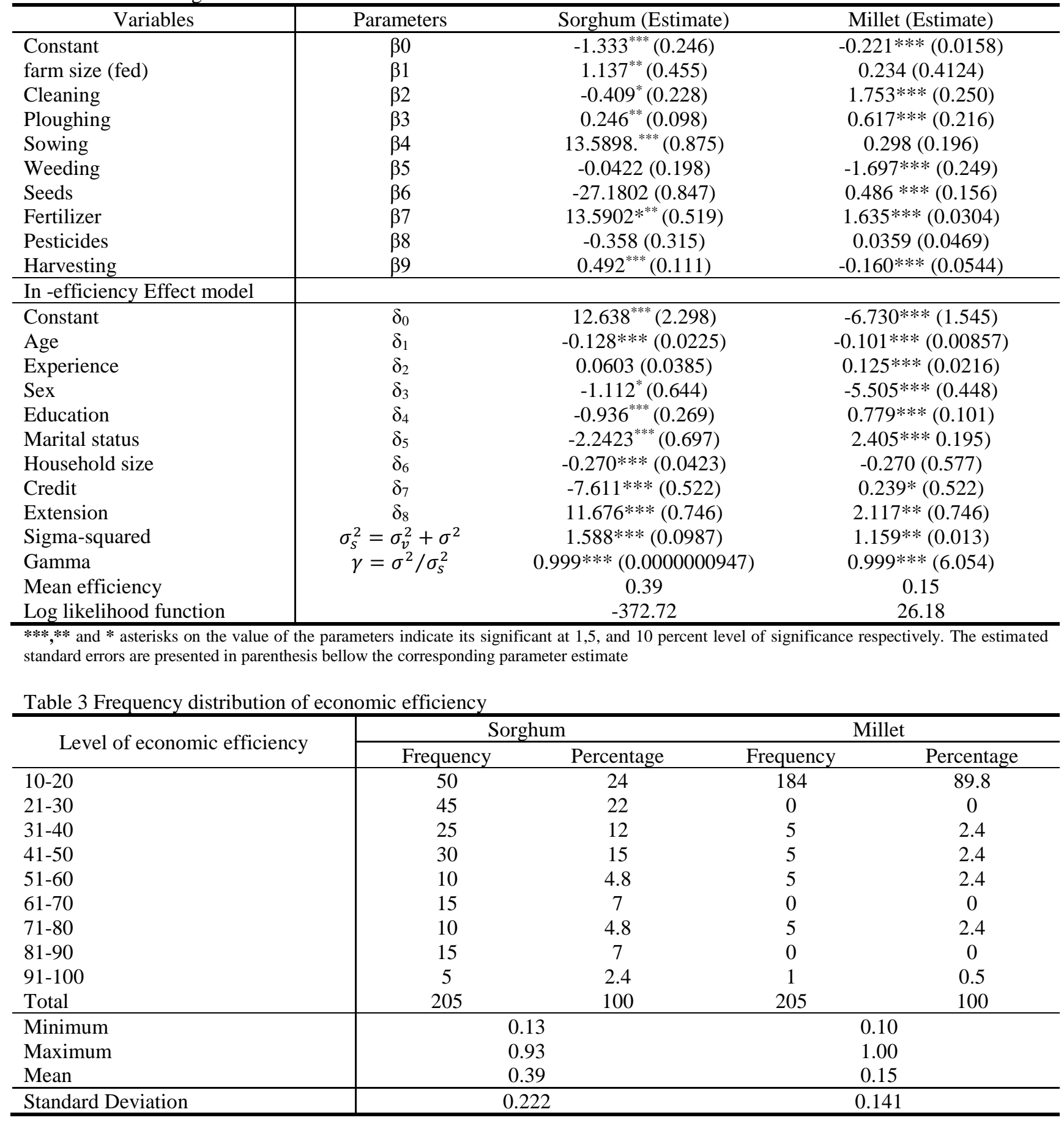

The coefficient of education variable is estimated to be negative as expected and statistically significant at the 0.01 level for sorghum and positive and significant at 0.01 level of significant for millet. The negative and significant finding agrees with comparable findings by Battese et al. (1995) and Coelli and Battese (1996). The implication negative and significant of education of farmers tends to be more efficient in production, due to their enhanced ability to acquire technical knowledge, which makes them move close to the frontier output. The negatively and statistically significant of education which means that the education of farmers increases inefficiency effect and decrease cost efficiency of sorghum, while negative and significant of education which means that the education of farmers decrease inefficiency effect and increase economic efficiency of millet production.

The positive significant which means that the inefficiency parameters (socioeconomic characteristics of farmers) increase inefficiency effect and decrease economic (cost) efficiency, while the negative and statistically significant means that the inefficiency parameters decreases inefficiency and increase economic efficiency. 


\section{Conclusion}

This study measures the economic efficiency of food crops production (sorghum and millet) in traditional rainfed sector, in this paper stochastic frontier cost function and descriptive statistical analyses was used. The results of the descriptive statistical analysis indicated that $76 \%$ of farmer's males, and the mean age were 44.08 years; also most farmers $(85.4 \%)$ are married and $(63.4 \%)$ have attained some sort of education. An average economic efficiency estimated of the sorghum and millet farmers obtained was found to be $0.39(39 \%)$ and 0.15 $(15 \%)$, respectively. the result reveal that there is a significant inefficiency effect in sorghum and millet production in traditional rainfed sector, found that $99 \%$ production associated with inefficiency. Based on findings, the study recommends that economic efficiency can be achieved through improved farmer specific efficiency factors, which include improved farmer education, access to credit, and access to improved extension services. In addition to that and enhancing institutional promotion of agricultural research sectors, and investment in agriculture to raise agricultural productivity. If the farmers address the inefficiency determinants sorghum and millet production will be maximized in the rainfed sector in North Kordofan state.

\section{References}

Ahmed AE. 1996. Productivity and Resources Allocation Efficiency of Major Field Crops in the Gezira Scheme, M.Sc Thesis, University of Khartoum, Sudan.

Anonymous. 2017a. Agriculture. https://content.ghanagrio.com/ article/269-agriculture.html [Accessed: 13.01.2013].

Anonymous. 2017b. Land tenure. http://wikimediafoundation.org/ wiki/Fundraising [Accessed: 01.01.2017].

Battese GE, Coelli TJ. 1995. A Model for Technical In-efficiency Effect in a Stochastic Frontier Production Function for Panel Data. Empirical Econ., 20: 325-332.

Coelli TJ. 1996. A Guide to frontier version 4.1c. A Computer programme for Stochastic Frontier production and Cost Function Estimation", Working paper 96/07, Centre for Efficiency and Productivity Analysis Dept. of Econometrics, University of New England, Armidale, Australia.

Esmaeili A, Sadeghpour A, Hosseini SMB, Jahanzad E, Chaichi MR, Hashemi M. 2011. Evaluation of seed yield and competition indices for intercropped annual medic-barley. International Journal of Plant Production, 4: 395- 404.

FAO. 2010. Assessment mission report for crop production and food security assessment for the northern states of Sudan. http://www.fao.org/fileadmin/user_upload/sifsia/docs/Cereal_A vailability_Survey_in_Northern_Sudan_Aug10.pdf.
Farrell JM. 1957. The Measurement of Productive Efficiency" The Journal of Royal statistical Society. 506 volume 120, Part III pp $253-290$.

Hashemi M, Farsad A, Sadeghpour A, Weis S, Herbert SJ. 2013. Cover crop seeding date influence on fall nitrogen recovery. J Plant Nutr. Soil Sci. 176: 69-75.

Jahanzad E, Jorat M, Moghadam H, Sadeghpour A, Chaichi MR, Dashtaki M. 2013. Response of a new and a commonly grown forage sorghum cultivar to limited irrigation and planting density. Agr. Water Manage. 117: 62-69.

Malik AA. 1984. The Effects of Some Socio-economic Factors on Sugar Cane Production. M.Sc Thesis. Department of Rural Economy. Faculty of Agriculture, University of Khartoum. Sudan.

Mohammed O, Saeed M, Mahmoud A. 2009. Importance and Geographic Extent of Rain-fed Agriculture, National Symposium on Rainfed Agriculture in Sudan, University of Khartoum, UNESCO Drought Chair.

Ranaivoarison R. 2004. Land Property Rights and Agricultural Development in the Highlands of Madagascar: Economic and Environmental Implications, Farming and Rural Systems Economics, Volume 56.

Sadeghpour A, Jahanzad E, Esmaeili A, Hosseini SMB, Hashemi M. 2013a. Forage yield, quality and economic benefit of intercropped barley and annual medic in semi-arid conditions: Additive series. Field Crops Res. 148:43-48.

Sadeghpour A, Jahanzad E, Hashemi M, Esmaeili A, Herbert SJ. 2013b. Intercropping annual medic with barley may improve total forage and crude protein yield in semi-arid condition. Aust. J. Crop Sci.7(12): 1822-1828.

Sadeghpour A, Jahanzad E. 2012. Seed yield and yield components of intercropped barley (Hordeum vulgare L.) and annual medic (Medicago scutellata L.). Aust. J. Agric. Eng. 3: 47-50.

Sadeghpour A, Jahanzad E, Lithourgidis AS., Hashemi M, Esmaeili A, Hosseini MB. 2014. Int. J Plant Prod. 8(1): 77-89.

Sayed Ali FEZ, Salah MM, Maruod EM, Elrashied EE, Tarig EM. 2014. Climate Variability and Change: Implications for Household Food Security in North Kordofan State, World Essays Journal, 1(1): 13-19,

Schmidt P, Lovell CAK. 1977. Estimating Technical and Allocative Inefficiency Relative to Stochastic Production and Cost Frontiers. J. of Econometrics, 343-366.

Siddig RA. 1999. The Economics of Crop Production Under The Different Land Tenure Systems in Merowe Province, M.Sc Thesis, Department of Agricultural Economy, Faculty of Agriculture, University of Khartoum, Sudan.

Zandvakili OR, Allahdadi I, Mazaheri D, Akbari GA, Jahanzad E, Mirshekari M. 2012. Evaluation of quantitative and qualitative traits of forage sorghum and lima bean under different nitrogen fertilizer regimes in additive-replacement series. J. Agr. Sci.6: 223-235.

Zandvakili OR, Allahdadi I, Mazaheri D, Akbari GA, Jahanzad E, Mirshekari M. 2013. Effect of different planting proportions and nitrogen fertilizer in intercropping forage sorghum and lima bean. African Journal of Agricultural Research. 8(49): 64886498. 